\title{
Targeting NF-кB Signaling for Multiple Myeloma
}

\author{
Ada Hang-Heng Wong ${ }^{1,2, *(\mathbb{D})}$, Eun Myoung Shin ${ }^{1} \mathbb{C}$, Vinay Tergaonkar ${ }^{1,3,4}$ and \\ Wee-Joo Chng $5,6,7, * \mathbb{D}$
}

1 Laboratory of NF-kB Signaling, Institute of Molecular and Cell Biology (IMCB), Agency for Science, Technology and Research (A*STAR), Singapore 138673, Singapore; shinem@imcb.a-star.edu.sg (E.M.S.); vinayt@imcb.a-star.edu.sg (V.T.)

2 AW Medical Company Limited, Macau, China

3 Department of Pathology, Yong Loo Lin School of Medicine, National University of Singapore, Singapore 119074, Singapore

4 Department of Centre for Cancer Biology, University of South Australia and SA Pathology, Adelaide, SA 5000, Australia

5 Cancer Science Institute of Singapore, Singapore 117599, Singapore

6 Department of Medicine, Yong Loo Lin School of Medicine, National University of Singapore, Singapore 119228, Singapore

7 Department of Hematology-Oncology, National University Cancer Institute of Singapore, National University Health System, Singapore 119074, Singapore

* Correspondence: wonghh@imcb.a-star.edu.sg (A.H.-H.W.); mdccwj@nus.edu.sg (W.-J.C.); Tel.: +65-6586-9709 (A.H.-H.W.); +65-6772-4612 (W.-J.C.)

Received: 12 July 2020; Accepted: 1 August 2020; Published: 6 August 2020

check for updates

\begin{abstract}
Multiple myeloma (MM) is the second most common hematologic malignancy in the world. Even though survival rates have significantly risen over the past years, MM remains incurable, and is also far from reaching the point of being managed as a chronic disease. This paper reviews the evolution of MM therapies, focusing on anti-MM drugs that target the molecular mechanisms of nuclear factor kappa B (NF- $\mathrm{kB}$ ) signaling. We also provide our perspectives on contemporary research findings and insights for future drug development.
\end{abstract}

Keywords: multiple myeloma; NF-kB; biomarker-guided targeted therapy; precision medicine

\section{Background}

Multiple myeloma (MM) is the second most common hematologic malignancy, accounting for $1 \%$ of all cancers globally in 2016 [1]. MM mainly occurs in older people, with a median age of 66-70 years at the time of diagnosis [1]. Age demography significantly contributes to MM progression and regimen design [2,3]. Survival rates are higher in younger people, partially due to the feasibility of autologous stem cell transplant (ASCT) and better drug tolerability during adjuvant therapy to ASCT or non-transplant systemic therapy. Nevertheless, overall survival rates have risen significantly over the past decades [4,5], with a five-year survival rate of 53.9\% between 2010 and 2016 in the United States (US) [5]. Improved outcomes resulted from a significant increase of the use of novel therapies, including proteasome inhibitors and immunomodulatory drugs (IMiDs), which increased from 8.7\% in 2000 to $61.3 \%$ in 2014 in US patients [6]. Additionally, the introduction of low-dose continuous therapy and maintenance therapy schemes post-ASCT or high-dose induction therapy also contributed to improved clinical outcomes, mainly through palliating adverse effects to increase drug tolerability, especially in weak elderly patients [7]. Aside from improvements in therapeutic design, novel drugs are designed to target specific molecular mechanisms involved in $\mathrm{MM}$, especially the nuclear factor kappa B (NF-KB) signaling pathway [8-10], which is described in the following context. 


\section{Multiple Myeloma and NF- $\kappa B$ Signaling}

Myeloma, also known as plasma cell myeloma, is the accumulation of malignant plasma cells in the bone marrow. Initially, in the asymptomatic phase (known as smoldering myeloma), myeloma cells produce abnormally substantial amounts of monoclonal proteins (M-proteins) that are released to the blood stream. As the disease progresses to the symptomatic phase, known as MM, the myeloma cells harness the bone marrow microenvironment to promote growth and invasion. MM progression leads to bone destruction, hypercalcemia and renal insufficiency, and may result in patient lethality.

$\mathrm{MM}$ is linked to the frequent onset of hyperploidy, chromosomal aberrations, genetic mutations and epigenetic transformations. Among these anomalies, hyperploidy is most prevalent, contributing to nearly half of all MM cases [11]. In non-hyperploid MM, chromosomal aberrations at the B cell class switching gene locus IGH frequently occur, leading to aberrant production of M-proteins in MM patients $[12,13]$. Aside from chromosomal changes, genetic mutations common in cancers frequently occur in MM too, e.g., the oncogenic KRAS and NRAS transformations and loss-of-function TP53 mutations [11,14-16]. Some genetic modifications are more MM-specific and contribute to hyperactive NF- $K B$ signaling. These include the amplification or rearrangement of NIK, LTBR, TACI, NFKB1, NFKB2 and $C D 40$ genes, as well as deletion or loss-of-function mutations in genes like $C Y L D, B I R C 2 / B I R C 3$ (cIAP1/CIAP2), TRAF2 and TRAF3 [17]. On the other hand, MM progression displays distinct epigenetic landscape changes. For example, extensive DNA hypomethylation in non-CpG islands occurs during the transition from monoclonal gammopathy of undetermined significance to the myeloma stage [18]. Moreover, hypermethylation of a subset of transcription factors, e.g., FOXD2, GATA4, RUNX2, and cell cycle-related genes, e.g., $C D K N 2 B$, potentially remodels cellular processes to promote tumorigenesis [18]. Furthermore, MM development is supported by the promoter methylation of the P53 gene, which is sustained by the NF-kB-regulated cytokine interleukin-6 (IL-6) [19]. Aside from DNA methylation, histone modifications such as acetylation and methylation also significantly alter the epigenetic landscape and drug response of MM [20]. For instance, overexpression of the histone methyltransferase gene $E Z H 2$ that frequently occurs in MM may be induced by hyperactive non-canonical NF- $\mathrm{KB}$ signaling [21]. Inhibition of EZH2 sensitizes MM to bortezomib treatment in vivo, through cooperative $M Y C$ suppression and inhibition of $\mathrm{H} 3 \mathrm{~K} 27$ trimethylation to regulate genes involved in B cell metabolism and antibody production [22,23]. NF- $\mathrm{kB}$ gene mutations are known to be the most prevalent in MM among all human cancers $[14,15,17,24,25]$, and plays a pivotal role in anti-cancer therapy and drug resistance [26-29].

NF- $\mathrm{KB}$ refers to a family of transcription factors that form homo- and hetero-dimers within the family, as well as with other transcription factors [30]. NF- $\mathrm{kB}$ signaling is classified into the canonical and non-canonical pathways that are represented by the transcriptional protein complexes of p50/RelA and p52/RelB, respectively [31]. These two pathways are activated by distinct membrane receptors that respond to extracellular ligands like tumor necrosis factor $\alpha$ (TNF $\alpha$ ), interleukin-1 (IL-1), receptor activator of NF-KB ligand (RANKL), and so on (Figure 1). In canonical NF- $\mathrm{kB}$ signaling, receptor activation leads to formation of the TRAF2-TRAF5-TRAF6 complex, which activates TAK1 kinase to phosphorylate the complex of IKK $\alpha$, IKK $\beta$ and NEMO. IKK complex phosphorylation subsequently triggers the degradation of $I \kappa B$ to release the p105 protein for proteasomal processing to the p50 protein. Consequently, the p50/RelA complex translocates to the nucleus and initiates transcription. Non-canonical NF-KB signaling involves the TRAF2-TRAF3-TRAF6 complex, which activates the NIK kinase to phosphorylate the IKK $\alpha$ kinase. Phosphorylated IKK $\alpha$ then triggers proteasomal processing of p100 to p52 for transcriptional activation. Although the canonical and non-canonical pathways have variant triggering signals and downstream targets, both pathways are involved in MM pathogenesis and progression $[15,24,25]$. 


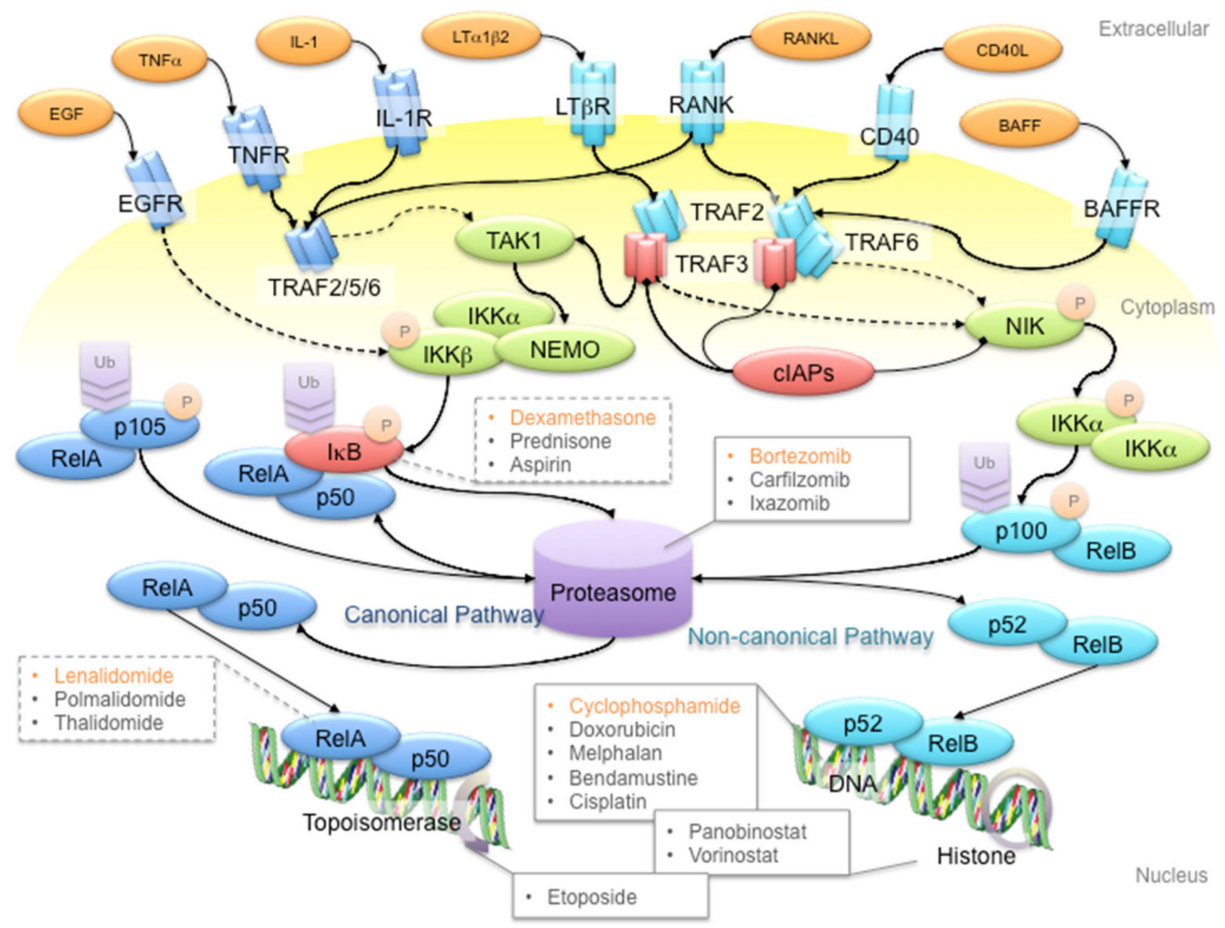

Figure 1. Schematic diagram of the NF- $\kappa B$ signaling pathway and anti-multiple myeloma (MM) drug targets. First-line anti-MM drugs (highlighted in orange) passively target the canonical and/or non-canonical pathways to shut down NF- $\mathrm{kB}$ signaling. For example, bortezomib inhibits the $26 \mathrm{~S}$ proteasome to hinder the processing of p105 and p100 proteins, to prevent gene transcription activation in canonical and non-canonical NF- $\mathrm{kB}$ signaling pathways, respectively; dexamethasone induces IкB protein synthesis to inhibit p105 processing; lenalidomide reduces RelA binding to open chromatin; cyclophosphamide is a DNA alkylating agent that disrupts DNA replication and genome stability. Ligands, adaptor proteins and transcriptional complexes involved in canonical NF- $\mathrm{kB}$ signaling are depicted in dark blue, whereas those involved in non-canonical NF- $\mathrm{kB}$ signaling are depicted in light blue; kinases are depicted in green; inhibitors are depicted in red. P and Ub indicate the post-translational modifications of phosphorylation and ubiquitination, respectively. Arrows with triangle heads indicate activation, whereas arrows with rhomboid heads indicate inactivation/inhibition; direct interactions are indicated by solid lines, whereas indirect interactions are indicated by dash lines.

NF- $\mathrm{kB}$ signaling plays a pivotal role in promoting cancer growth, angiogenesis and tumormicroenvironment crosstalk, which mainly involves the production of pro-inflammatory cytokines, inflammation mediators, cell adhesion molecules, among others, to establish a favorable tumor microenvironment for MM tumorigenesis and disease progression. Non-canonical NF- $\mathrm{kB}$ signaling is also a key determinant of other oncogenic drivers, such as telomerase and telomeric proteins, which are commonly deregulated in cancers [32-35]. NF- $\mathrm{kB}$ signaling, in combination with other potent transcription factors such as STAT3, also plays important roles in regulating apoptosis and polarization of immune subtypes, which contribute to a pro-tumoral microenvironment [36,37]. Hence, many first-line anti-MM drugs have an indirect impact on the NF- $\mathrm{kB}$ signaling pathway (Figure 1). For instance, bortezomib is a reversible inhibitor of the $26 \mathrm{~S}$ proteasome [38] and thus prevents the proteasomal cleavage of NF- $\mathrm{KB}$ proteins and the I $\mathrm{B}$ protein to inhibit gene transcription activation. The insult of bortezomib on MM cells is further enhanced by the fact that the proteasome is overloaded by excessive M-protein production in myeloma cells. On the other hand, the corticosteroid dexamethasone induces inhibitor of $\kappa B(\mathrm{I} \kappa \mathrm{B})$ protein synthesis to inhibit NF- $\mathrm{kB}$ signaling [39]. Another first-line therapy drug, the IMiD lenalidomide, diminishes sustained RelA binding to open chromatin by inhibiting the Ikaros proteins Ikzf1 and Ikzf3 [40-42]. Co-administration of lenalidomide and 
dexamethasone suppresses interleukin-2 (IL-2), immunoglobin M (IgM) and immunoglobin G (IgG) production, hence reducing the protein load of MM patients [43]. In recent years, immunotherapy using antibodies and chimeric antigen receptor T (CAR-T) cells against specific NF- $\mathrm{kB}$ signaling receptors has gained more attention. For example, antibodies against $\mathrm{B}$ cell-activating factor (BAFF) inactivate non-canonical NF- $\mathrm{kB}$ signaling in MM cells [44,45]. Clinical trials are ongoing, so it is still too early to conclude whether any of these strategies works.

In addition to intracellular NF- $\mathrm{kB}$ hyperactivation, $\mathrm{MM}$ cells also manipulate NF- $\mathrm{kB}$ signaling in the bone marrow microenvironment to promote cancer growth and invasion (Figure 2). On the one hand, myeloma cells hijack stromal cells to secrete cytokines, such as interleukin-6 (IL-6), receptor activator of NF- $\mathrm{kB}$ ligand (RANKL) and vascular endothelial growth factor (VEGF), to promote cancer proliferation and angiogenesis [46]. On the other hand, myeloma cells secrete Dickkopf-1 (Dkk1) and macrophage inflammatory factor $1 \alpha$ (MIP-1 $\alpha$ ) to inhibit osteoblast differentiation to block new bone formation, and activate osteoclasts to promote osteolysis [47,48]. In late-stage MM patients, the myeloma cells acquire additional genetic abnormalities that lead to reduced dependency on the microenvironment (e.g., P53 mutation), increased drug resistance and increased aggressiveness of the clone (e.g., 1q21 amplification and CKS1B overexpression) [49]. Hence, therapies against both MM cells and microenvironment control, such as daratumab, an antibody drug against CD38 that induces antibody-dependent cytotoxic events in CD38-expressing cancer cells and complement-dependent cytotoxicity [50-52], show success in MM treatment [53].

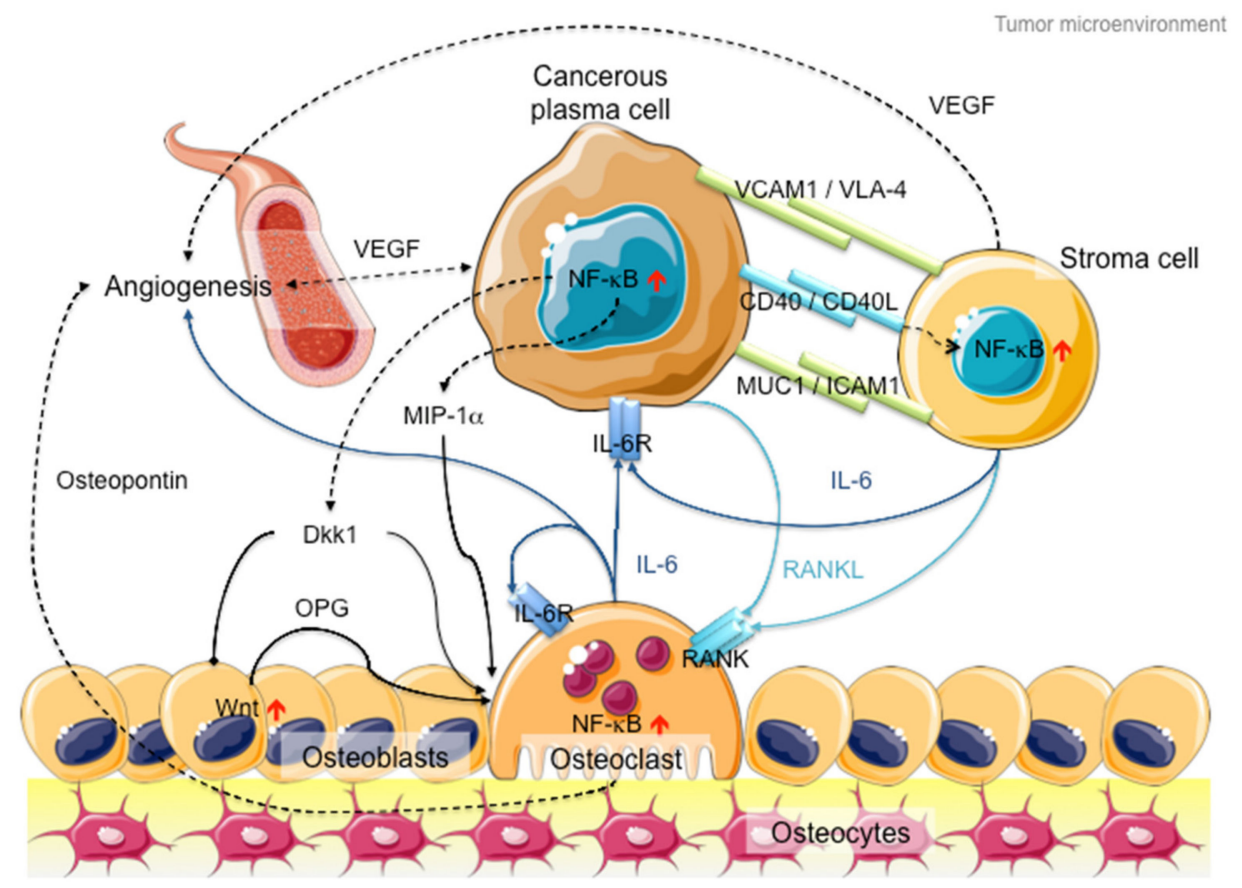

Figure 2. Schematic diagram of the MM microenvironment. Cancerous plasma cells interact with stroma, osteoblasts and osteoclasts through membrane receptor interactions and secretory cytokine pathways. Hyperactive NF- $\mathrm{KB}$ signaling plays a pivotal role in disease progression through transcriptional activation of the secretion of various cytokines like IL-6, RANKL and Dkk1 to promote cancer cell proliferation, osteoblast inactivation, osteoclast hyperactivation and angiogenesis. Proteins involved in canonical NF- $\mathrm{kB}$ signaling are indicated in dark blue, whereas proteins involved in non-canonical NF- $\mathrm{BB}$ signaling are indicated in light blue. Arrows with triangle heads indicate activation, whereas arrows with rhomboid heads indicate inactivation/inhibition; direct interactions are indicated by solid lines, whereas indirect interactions are indicated by dashed lines. Artistic images were downloaded from Servier Medical Art (https://smart.servier.com/; Servier Medical Art by servier is licensed under a creative commons attribution 3.0 unported license). 
Even though receptor-/ligand-specific antibodies can target NF- $\mathrm{kB}$ signaling with high specificity, the diverse NF- $\mathrm{KB}$ signals in MM cells and their microenvironment limit the application of these therapies to treat $\mathrm{MM}$ effectively in vivo. Tumor evolution also contributes to altering pathways to develop drug resistance. Hence, directly targeting the molecular machinery of NF- $\mathrm{KB}$ signaling remains crucial. Until now, no specific NF- $\mathrm{KB}$ inhibitor has been approved for treating MM. We will discuss the challenges of developing specific NF- $\mathrm{KB}$ inhibitors for MM treatment.

\section{NF- $k$ B Signaling: The Rose with Thorns in MM Treatment}

Even though NF- $\mathrm{kB}$ signaling plays a critical role in MM, specifically targeting this signaling pathway proves to be more difficult than previously thought.

The foremost hurdle is drug safety. NF- $\mathrm{kB}$ signaling plays a key role in innate immunity and inflammation. Constitutive inactivation of NF-KB signaling silences the immune system, subsequently rendering patients susceptible to infections. Population-based studies have pointed out that MM patients displayed a seven-fold higher risk of bacterial infection and a 10-fold higher risk of viral infections as compared to randomized control individuals, resulting in a stunning $22 \%$ death rate among MM patients at one-year follow-up [54]. It is noteworthy that transplanted patients displayed a broader spectrum of infection [55], where infection rate may be reduced by combined IMiD therapy [56], due to the fact that immunosuppressive drugs are administered to prevent graft-versus-host defense. On the other hand, bortezomib-based therapy is associated with a higher risk of severe infection in various studies [56-58], possibly through inhibition of both canonical and non-canonical NF-kB pathways. Hence, it is hypothesized that targeting of one NF- $\kappa B$ pathway may be safer than inactivating both NF- $\kappa B$ signaling pathways. Nevertheless, trials of many IKK $\beta$ inhibitors showed severe adverse effects [59], even though non-canonical NF- $\mathrm{kB}$ signaling is hypothesized to be unaffected. In contrast, the anti-RANK antibody denosumab, which is recommended as adjuvant therapy to MM patients to alleviate hypercalcemia due to hyperactive osteoclasts [60], produces little toxicity but cannot treat MM because of its narrow-spectrum inhibition of RANK-mediated non-canonical NF- $\kappa B$ signaling. Hence, striking the right balance between drug safety and treatment efficiency remains challenging.

Secondly, the context-specific and spatio-temporal regulation of NF- $\mathrm{kB}$ signaling complicates therapeutic design. This complexity is further complicated by the interplay between cancer and its immune microenvironment $[26,46,61,62]$. For example, the non-steroidal anti-inflammatory drugs (NSAIDs) (e.g., aspirin, sulindac and tolfenamic acid) that target the COX-1/2 genes may suppress NF- $\kappa B$ signaling during short-term administration but activate NF- $\kappa B$ signaling after prolonged treatment [59].

Thirdly, selectivity remains a critical issue. For instance, several IKK $\beta$ inhibitors exhibit off-target effects, whereas others display high selectivity toward IKK $\beta$ and loss of inhibition through IKK $\alpha$ [59]. In this regard, combined treatment may offer hope for highly selective inhibitors, but this also requires more consideration of the treatment burden on patients, especially when many MM patients are old and weak. Nevertheless, high selectivity suffers from poor treatment efficiency. For instance, the anti-BAFF antibody tabalumab, which specifically inhibits non-canonical NF- $\mathrm{kB}$ signaling, failed to improve outcomes in MM patients in a phase II trial in which it was combined with bortezomib and dexamethasone [63].

Lastly, the lack of structural information hampers rational drug design, although solving the structure does not guarantee success either. For example, structure of the NF- $\mathrm{kB}$ inducing kinase (NIK) has been solved [64], but the NIK inhibitors AM-0216 and AM-0561 failed due to poor pharmacokinetics in vivo, even though they displayed high NIK binding affinity and NIK-dependent cytotoxicity in vitro [65]. On the contrary, a peptide mimetic of the NF- $\mathrm{KB}$ essential modulator (NEMO) binding domain that blocks IKK complex formation [66] made its way to clinical trials in dogs for treating diffuse large B cell lymphoma (DLBCL) and soft tissue sarcoma (STS) [67], but no clinical trial has been reported to treat humans. Other molecular targets might lack specific inhibitors after solving 
the structure [68]. Consequently, no specific NF-kB inhibitor has been successfully developed to treat MM until now.

\section{MM Therapy: A Steep Road to Success}

MM therapy mainly involves stem cell transplant and systemic drug therapy with occasional use of radiotherapy for plasmacytomas (Figure 3). ASCT is an important treatment modality for MM patients, whereas allogeneic stem cell transplant is suggested for high-risk patients with complex karyotypes [69]. However, allogeneic stem cell transplant is still rarely used in MM patients because of high rates of treatment-related mortality. Furthermore, stem cell transplant is often infeasible because of the frailty of MM patients, who are mostly elderly, aged 65 and above. Hence, systemic drug therapy remains an indispensable approach for MM treatment. Similar to many other cancers, MM is often treated by a combination of drugs.

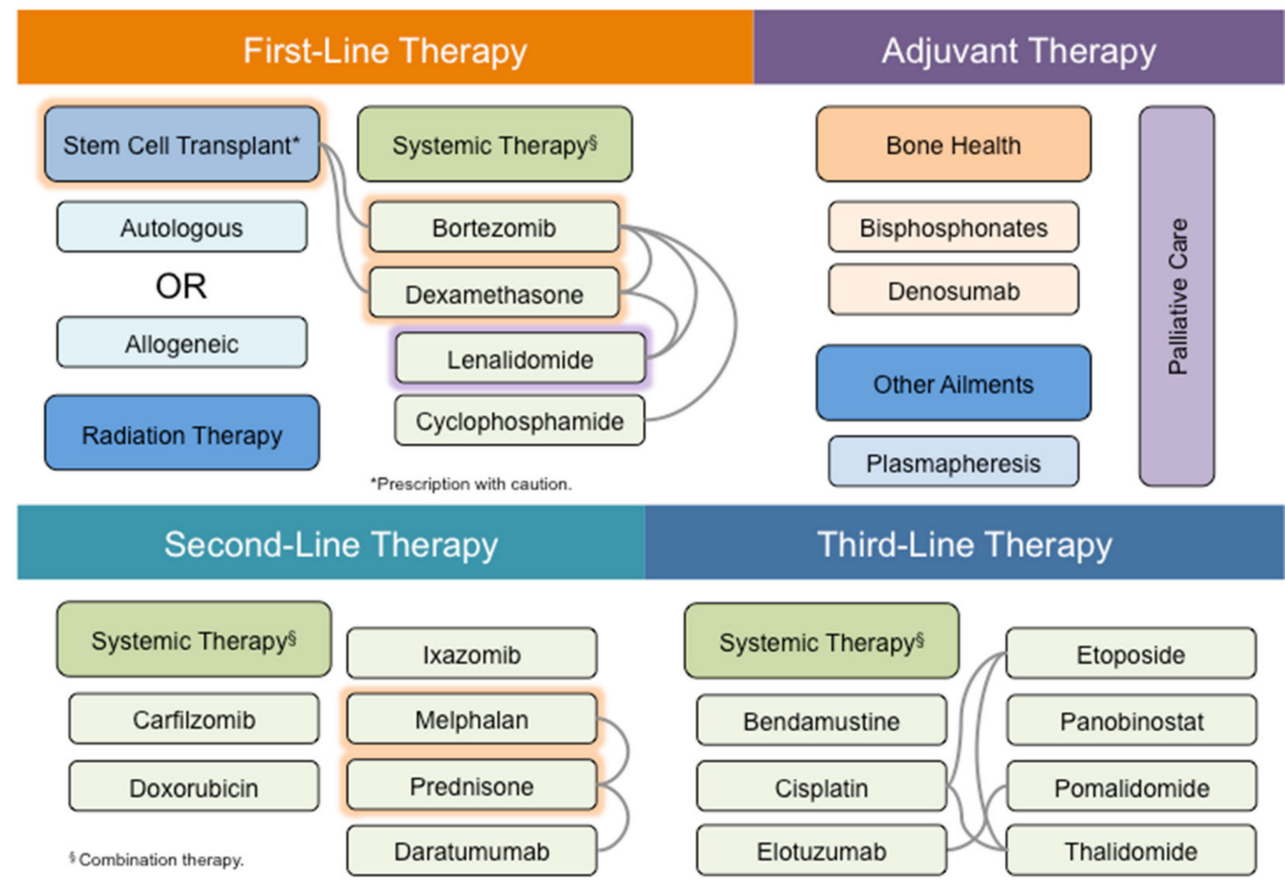

Figure 3. Therapeutic options of MM. Systemic therapy is the most common treatment option for MM patients. Systemic therapy is usually administered in a combined manner, with synthetic drugs and antibodies (green box), or in conjunction with stem cell transplant (cyan box). For example, bortezomib and dexamethasone constitute the adjuvant therapy for stem cell transplant patients in first-line therapy (shadowed in orange and connected by gray lines). On the other hand, melphalan and prednisone are recommended for non-transplant patients in first-line therapy (shadowed in orange and connected by gray lines). Alternatively, lenalidomide may be recommended with bortezomib and dexamethasone in non-transplant patients in first-line therapy (connected by gray lines) or administered alone during palliative care (shadowed in purple). Therapeutic options are color-coded in boxes according to their application and placed or shadowed under the categories of first-line (orange), second-line (cyan) and third-line (blue) therapy, or palliative care (purple), according to the frequency of recommendation for clinical use under the National Comprehensive Cancer Network (NCCN) guidelines. Combination therapies on the same line of therapy are connected by gray lines, whereas those spanning across different lines of therapy are not indicated.

Among these drugs, bortezomib is the most frequently used drug for MM treatment. Bortezomib is commonly paired with IMiDs such as lenalidomide and thalidomide, or alkylating agents such as melphalan, cyclophosphamide and dexamethasone. Dexamethasone, lenalidomide and prednisone all exhibit anti-inflammatory responses. On the other hand, melphalan is a DNA alkylating drug that has 
been used to treat MM since the 1950s [70]. Among all these drugs, melphalan and prednisone are the oldest drugs used in MM treatment [71]. It is noteworthy that combination therapy is usually used for MM treatment, often as a means of exploiting drugs with different mechanisms of action.

Existing anti-MM drugs target a diverse array of molecular pathways (Table 1). Analysis of the recommended drugs along the lines of therapy, together with those undergoing clinical trials, displays an interesting trend (Figure ??). Briefly, anti-inflammatory drugs take a central role in MM therapy and are applied to both standard therapy and maintenance therapy for MM patients, given the pivotal role of NF- $\mathrm{kB}$ and inflammation in MM progression. Next, the impact of protein secretion load in myeloma cells and the resultant endoplasmic reticulum stress make the cells vulnerable to inhibition of the proteolysis pathways. Therefore, proteasome inhibitors, including bortezomib and carfilzomib, often make up a base for different combination therapies. Aside from the MM-specific mechanisms, drugs that disrupt DNA and RNA synthesis, promote cell death and inhibit angiogenesis are frequently applied to MM treatment too. However, the most intriguing part is the increasing trend of other therapeutic mechanisms in drugs undergoing clinical trials or in research. The common mechanism of these drugs is the specific targeting of certain molecules or molecular pathways, especially NF- $\mathrm{kB}$ signaling. For instance, selinexor blocks exportin to retain NF- $\mathrm{kB}$ in the nucleus [72,73].

Table 1. Summary of anti-MM drug mechanisms.

\begin{tabular}{|c|c|c|c|c|c|c|c|c|c|}
\hline Drug Name & 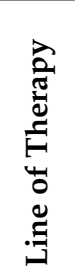 & 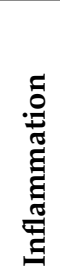 & 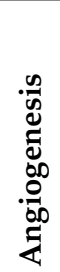 & 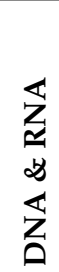 & 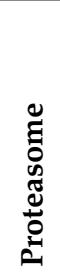 & 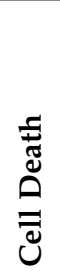 & $\begin{array}{l}\frac{0}{\tilde{J}} \\
\bar{d} \\
\bar{\Xi}\end{array}$ & 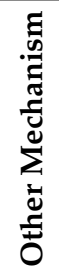 & Drug Target \\
\hline Bortezomib & 1 & & & & & & & & NF-kB \\
\hline Dexamethasone & 1 & & & & & & & & \\
\hline Lenalidomide & 1 & & & & & & & & VEGF, bFGF \\
\hline Cyclophosphamide & 1 & & & & & & & & DNA \\
\hline Carfilzomib & 2 & & & & & & & & Proteasome \\
\hline Daratumumab & 2 & & & & & & & & CD38 \\
\hline Doxorubicin & 2 & & & & & & & & Topoisomerase \\
\hline Ixazomib & 2 & & & & & & & & Proteasome \\
\hline Melphalan & 2 & & & & & & & & DNA \\
\hline Prednisone & 2 & & & & & & & & \\
\hline Bendamustine & 3 & & & & & & & & DNA \\
\hline Cisplatin & 3 & & & & & & & & DNA \\
\hline Elotuzumab & 3 & & & & & & & & CS1 \\
\hline Etoposide & 3 & & & & & & & & Topoisomerase \\
\hline Panobinostat & 3 & & & & & & & & HDAC \\
\hline Pomalidomide & 3 & & & & & & & & VEGF, bFGF \\
\hline Thalidomide & 3 & & & & & & & & VEGF, bFGF \\
\hline Abatacept & $\mathrm{CT}$ & & & & & & & & CD80, CD86 \\
\hline Abemaciclib & $\mathrm{CT}$ & & & & & & & & CDK4, CDK6 \\
\hline Acalabrutinib & $\mathrm{CT}$ & & & & & & & & BTK \\
\hline АСР-319 & $\mathrm{CT}$ & & & & & & & & PI3K \\
\hline ALT-803 & $\mathrm{CT}$ & & & & & & & & IL-15 \\
\hline ASA & $\mathrm{CT}$ & & & & & & & & COX-1/2 \\
\hline Atezolizumab & CT & & & & & & & & PD-L1 \\
\hline Avelumab & $\mathrm{CT}$ & & & & & & & & PD-L1 \\
\hline Azacitadine & $\mathrm{CT}$ & & & & & & & & DNA methylation \\
\hline AZD5991 & $\mathrm{CT}$ & & & & & & & & Mcl-1 \\
\hline Binimetinib & $\mathrm{CT}$ & & & & & & & & MEK-1/2 \\
\hline Busulfan & $\mathrm{CT}$ & & & & & & & & DNA \\
\hline Carmustin & $\mathrm{CT}$ & & & & & & & & DNA \\
\hline
\end{tabular}


Table 1. Cont.

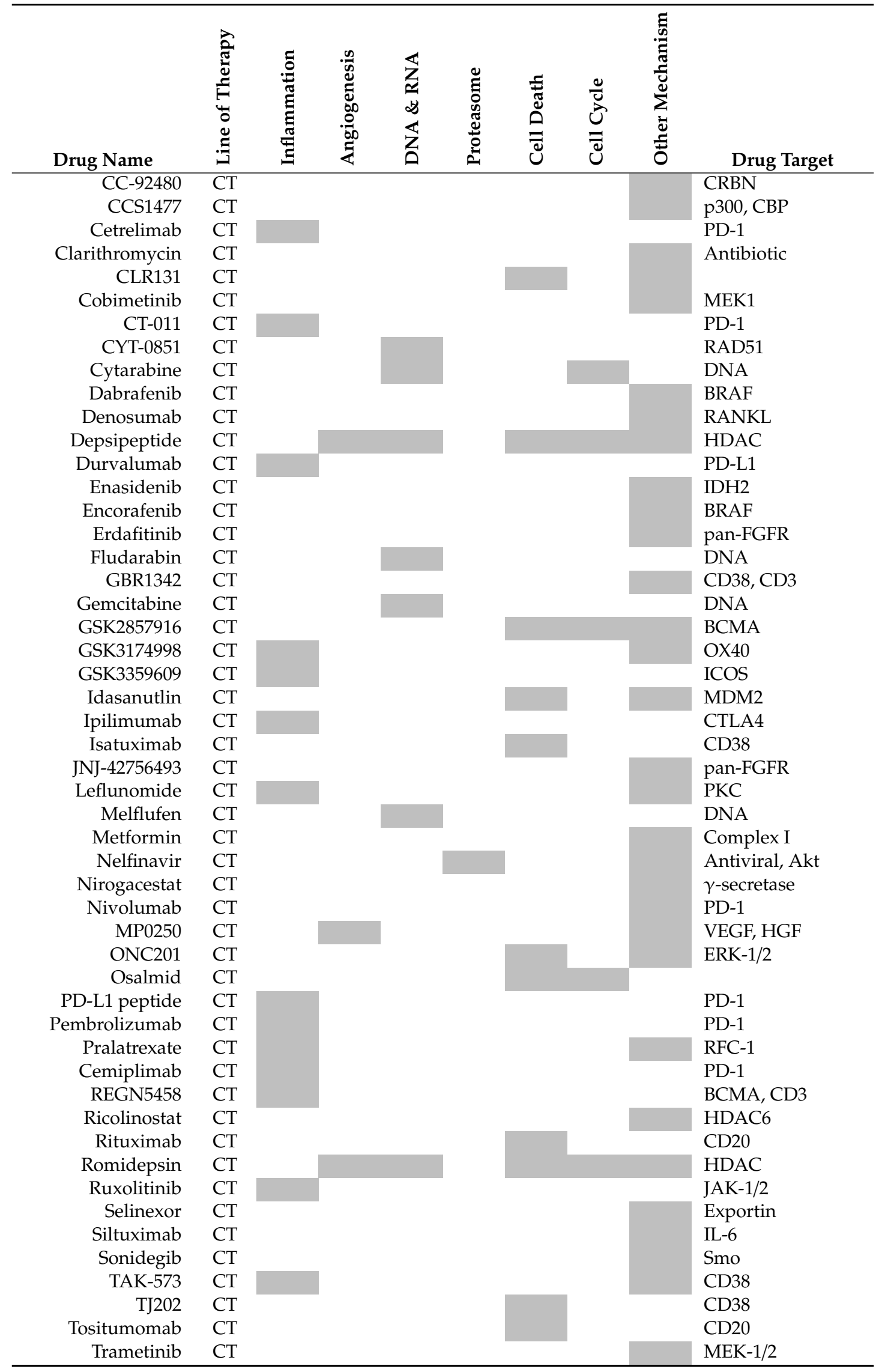


Table 1. Cont.

\begin{tabular}{|c|c|c|c|c|c|c|c|c|c|}
\hline Drug Name & 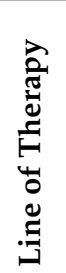 & 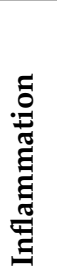 & 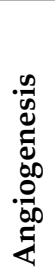 & 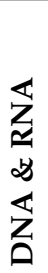 & 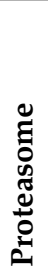 & 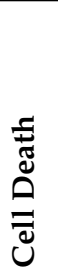 & $\begin{array}{l}\frac{0}{\tilde{J}} \\
\frac{\tilde{u}}{\overline{0}}\end{array}$ & 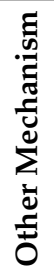 & Drug Target \\
\hline Venetoclax & $\mathrm{CT}$ & & & & & & & & Bcl-2 \\
\hline Vorinostat & $\mathrm{CT}$ & & & & & & & & HDAC \\
\hline Aspirin & NA & & & & & & & & COX-1/2 \\
\hline
\end{tabular}

The line of therapy of each drug is indicated by numbers according to the frequency of recommendation for clinical use under the National Comprehensive Cancer Network (NCCN) guidelines; drugs under active clinical trial according to clinicaltrials.gov as of 6 May, 2020, are indicated by "CT"; those that did not undergo clinical trial according to clinicaltrials.gov as of 6 May, 2020, are indicated by "NA". The mechanism of action of each drug is indicated in gray, based on drug labels disclosed by the Food and Drug Administration (FDA) and literature search. The known targets of respective drugs are listed in the rightmost column. For drugs indicated as "CT", the following criteria were applied in our search: (1) "Condition" was multiple myeloma; (2) "Phase" included phases II, III and IV; (3) "Status" included recruiting, active not recruiting, enrolling by invitation and unknown status. Afterwards, the list of drugs was compiled into a table and those that did not meet any one of the following criteria were excluded from our analysis: (1) active clinical trials, inferred by the last update date lying within 5 years of the date of data retrieval; (2) Phase II and beyond, i.e., for trials in Phase I/II, confirmed progression by literature search to Phase II was required; (3) not included as adjuvant or palliative care in combinations for stem cell transplant, fever and pain management, etc.; (4) not included in pan-cancer trials, e.g., MATCH [NCT02465060] (https://clinicaltrials.gov/ct2/show/NCT02465060?id=NCT02465060\&draw=2\&rank=1), CAPTUR [NCT03297606] (https:/clinicaltrials.gov/ct2/show/NCT03297606?id=NCT03297606\&draw=2\&rank=1) or TAPUR [NCT02693535] (https://clinicaltrials.gov/ct2/show/NCT02693535?id=NCT02693535\&draw=2\&rank=1); (5) not banned from import in certain countries; and (6) not having multiple records of dose escalation and/or drug combinations in incomplete studies or study termination over the past 5 years, suggesting drug inefficacy.

\section{Future Direction: Biomarker-Guided Targeted Therapy}

The first paradigm shift in MM treatment occurred in early 2000s with the introduction of the first-in-class proteasome inhibitor bortezomib [71]. Research on the correlation between proteasome load and degradative capacity on the sensitivity of MM cells toward bortezomib was conducted [87], suggesting that the levels of M-proteins and proteasome expression can be biomarkers for proteasome inhibitor sensitivity. This incidence marks the start of evidence-based therapeutic design for MM treatment. However, even though bortezomib is highly effective, its severe neurotoxicity is often intolerable, leading to drop-offs in many studies [88]. This subsequently led to exploration of the oral alternative ixazomib, which exhibits lower neurotoxicity [89]. Additionally, second generation proteasome inhibitors with different chemical moieties were developed to improve outcomes and reduce adverse reactions. For instance, carfilzomib showed a better response than bortezomib in refractory MM [90-92]; its major adverse effects on the cardiac system also occurred in fewer patients [93]. These protocols have paved the way for more precise regimens for application to different patient subgroups.

Recently, Shin, et al. identified lymphocyte cytosolic protein 1 (LCP1) gene as a novel NF- $\mathrm{kB}$ target in TRAF3 or NIK mutant MM cells [94] (Figure 4). TRAF3 loss induces constitutively active NIK [95,96], which frequently occurs in MM patients $[8,14,17]$. B cell-specific TRAF3-/- mice developed MM and peripheral B cell hyperplasia [97-100].

LCP1 encodes for the L-plastin protein, which is required for sealing ring formation in osteoclasts [101], but not in bone formation by osteoblasts in vitro [102]. Secreted L-plastin by breast cancer cells mediates metastatic osteolysis in mice [103]. Despite its osteolytic function, L-plastin contributes to metastasis of breast cancer, melanoma and colon cancer [103-109]. Studies also reported that L-plastin is responsible for disease progression of bladder and kidney cancer [110,111], and homing of chronic lymphocytic leukemia (CLL) to bone marrow [112]. Analysis of transcriptomic data showed that $L C P 1$ overexpression is significantly correlated with poor overall and progression-free survival in MM patients [94]. 


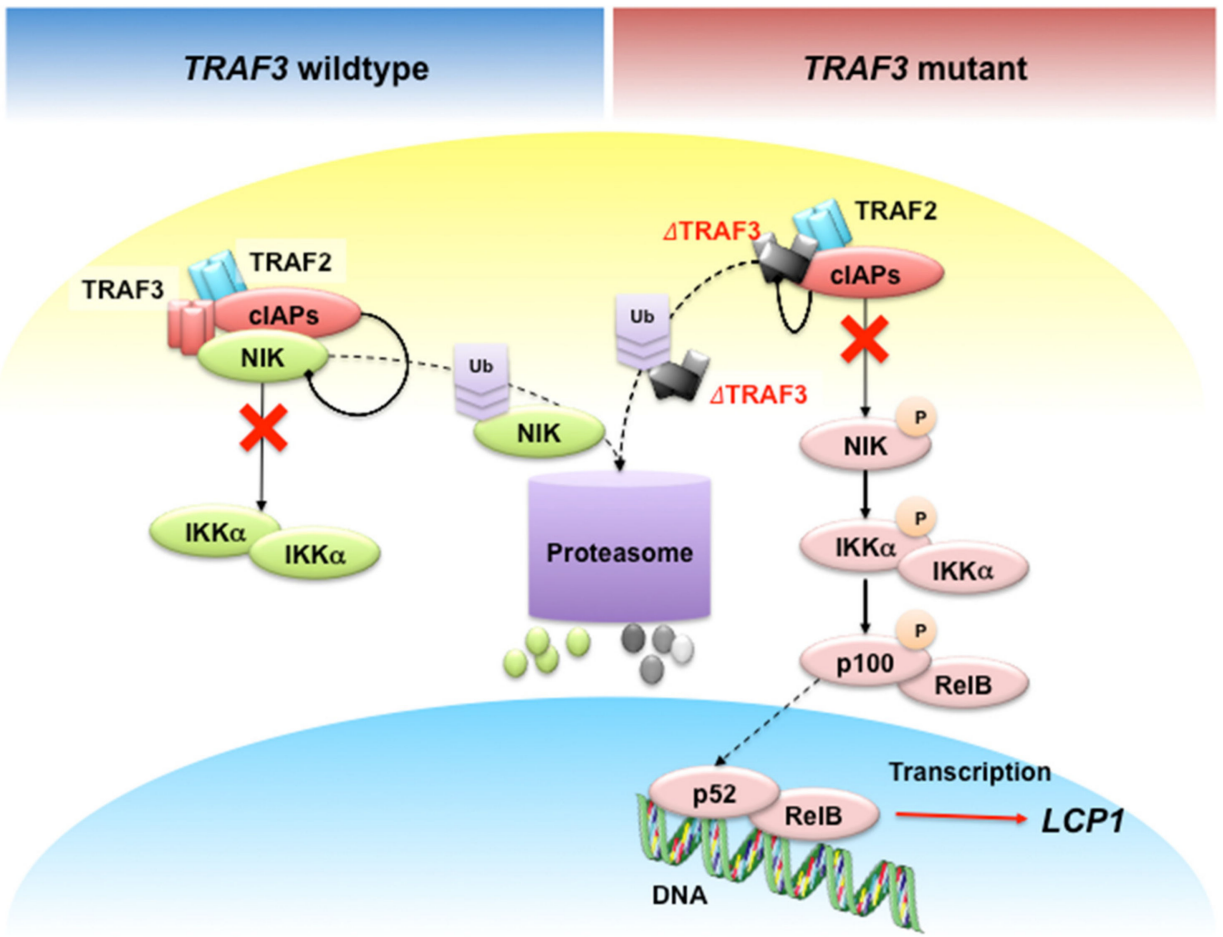

Figure 4. Constitutive NIK-driven NF- $\kappa B$ activation without functional TRAF3 in MM. In normal physiological conditions, TRAF3-TRAF2 interaction recruits the E3 ligases cIAPs to NIK to induce K48 ubiquitination, followed by proteasome-dependent degradation of NIK. In TRAF3-mutant MM cells, mutations in the TRAF or MATH domain of TRAF3 result in $\triangle T R A F 3$ proteins that are unable to interact with TRAF2 and NIK, thus stabilizing NIK to activate non-canonical NF- $\mathrm{BB}$ signaling. Arrows with triangle heads indicate activation, whereas arrows with rhomboid heads indicate inactivation/inhibition; direct interactions are indicated by solid lines, whereas indirect interactions are indicated by dashed lines.

L-plastin not only serves as a prognostic biomarker, but may also serve as a therapeutic target. For instance, radiotherapy represses exosomal release of L-plastin in both the tumor and its niche, producing radiation-induced bystander effects and enhance outcomes [113]. Inhibition of L-plastin Ser5 phosphorylation re-sensitizes resistant MM cells to IMiDs and proteasome inhibitors [114]. Collectively, these data suggest that inhibiting L-plastin provides an alternative route to treating $\mathrm{MM}$, specifically in TRAF3-mutant MM patients. In this regard, peptide inhibitors against L-plastin that inhibit osteoclast activity [102,115] might be tested. Alternatively, NIK inhibitors under development [82,83], or shown to repress inflammation in other mouse models [84,85], may be tested in MM mouse models too.

The revelation of $L C P 1$ 's involvement in TRAF3-mutant MM has led to deeper investigation of the role of calcium signaling in MM development and progression. It has been reported that calcium signaling activates NF-KB in B cells [116]. For instance, B cell receptor (BCR) activation stimulates store-operated calcium entry (SOCE) to induce NFKB2 expression [117], which encodes for p100 that is processed into $\mathrm{p} 52$ during non-canonical NF- $\mathrm{KB}$ activation. On the other hand, calcineurin A associates with TRAF3 and NIK to inhibit LT $\beta R$-mediated NIK activity and TWEAK-mediated p100 processing in fibroblasts [118]. Simultaneously, the calcineurin A-specific inhibitors cyclosporin A and FK506 inhibit IgM-induced B cell activation and trigger cell death [119]. Taken together, targeting L-plastin and calcium-dependent NF- $\mathrm{KB}$ activation may be favorable for MM therapy.

Massive chromosomal aberrations are a key feature of MM. Nearly half of MM tumors are hyperdiploid, usually comprising multiple copies of chromosomes 3, 5, 7, 9, 11, 15, 19 and 21 [11], whereas non-hyperdiploid MM tumors usually contain IGH translocations that do not involve c-myc $[12,13]$. This finding led to the proposal of patient risk group stratification based on molecular signatures of MM [11]. However, cytogenetic analysis of all known mutations might be unaffordable 
for the less-privileged, so resource-stratified guidelines are proposed to circumvent the cost issue [120]. In order to carry out patient risk group stratification, genetic test was suggested to be mandated as a routine clinical test for MM patients and subsequent clinical trials in 2009 [121]. Cytogenetic analysis is exploited to indicate allelic mutations relevant to regimen design. For example, homozygous carriers of the NFKB1 -94insATTG polymorphism were retrospectively demonstrated to benefit more from bortezomib treatment than MM patients carrying the deletion allele [122]. Bortezomib also exhibits a good response in del17p but not $\mathrm{t}(4 ; 14)$ patients and those with $1 \mathrm{q} 21$ gain, although its combination with lenalidomide and dexamethasone is promising in del17p, del1 $\mathrm{p}, \mathrm{t}(4 ; 14)$, and $\mathrm{t}(14 ; 16)$ patients [7]. Venetoclax is highly effective in $t(11 ; 14) \mathrm{MM}$ patients [123]. Furthermore, epigenetic changes have been correlated to certain cytogenetic subgroups. For example, extensive DNA hypomethylation is correlated to MM subgroups of hyperploidy, $\mathrm{t}(4 ; 14), \mathrm{t}(11 ; 14)$, and $\mathrm{t}(14 ; 16)$ translocations, but not the del1p, gain 1q, del13q, del16q, del17p and del22q subgroups [18]. Of note, $t(4 ; 14)$ translocation upregulates the histone methyltransferase multiple myeloma SET domain protein (MMSET) [124] and inhibition of MMSET activity inhibits MM cell proliferation in vitro [125]. Nevertheless, more research is needed to elucidate the correlation between different karyotypes and drug sensitivity.

Lastly, drugs to delay MM progression and prevent or re-sensitize MM to treatment are being investigated. For example, an antibody against IL-6 has been tried in smoldering myeloma patients to delay MM progression [126]. In addition, a potent multi-drug resistance modulator, valspodar, has been investigated to circumvent decreased drug deposition due to P-glycoprotein overexpression in response to therapy [127], but failed because of unimproved treatment outcomes and increased toxicity [128]. In contrast, nelfinavir sensitizes MM to overcome proteasome inhibitor resistance through modulating TCF11/Nrf1-mediated proteasome recovery [129]. Hence, drug development is striving incessantly to overcome the ever-evolving forms of drug resistance.

In addition to treatment efficacy, the tendency to trigger secondary neoplasm development is another key factor to consider during development of novel anti-MM drugs. Early small cohort studies showed that DNA alkylating drugs might possess a higher tendency to induce secondary neoplasms [130-132]. However, more recent study using a 403-patient cohort suggested that the therapeutic mechanism exhibited an insignificant impact; instead, complex karyotypes are largely correlated to the risk of developing secondary neoplasms [133]. Nevertheless, the skewed tendency of developing myelodysplastic syndrome (MDS) [130] warrants deeper investigation into therapy-related secondary neoplasms.

\section{Conclusions}

MM therapy has come a long way, evolving from the miscellaneous application of rhubarb and orange peel to the anti-proliferative melphalan and anti-inflammatory prednisone, to the first-in-class proteasome inhibitor bortezomib [71]. History has shown that MM treatment strategies evolved with our understanding of the molecular mechanism of MM progression. In this era of precision medicine, evidence-based therapeutic design has become the golden rule for regimen design. Regimen design considers factors like patient characteristics, therapeutic efficacy, working principle and adverse effects, among many others, from the scientific perspective. From the ethical point of view, treatment burden, quality of life and healthcare cost have received more attention in recent years. In parallel to treatment, diagnostic tests to identify biomarkers and predict treatment outcomes are routinely conducted in some countries. We predict that biomarker-guided targeted therapy will expand as our knowledge grows and continues to evolve in the next decade.

Author Contributions: A.H.-H.W. and E.M.S. contributed to literature search and data collection. A.H.-H.W., E.M.S., V.T. and W.-J.C. discussed the data analysis and interpretation. A.H.-H.W. prepared the figures. A.H.-H.W., E.M.S. and W.-J.C. prepared the manuscript. All authors have read and agreed to the published version of the manuscript.

Funding: AW Medical Company Limited received startup funding from the University Development Fund of University of Macau, Macau. 
Conflicts of Interest: The authors declare no conflict of interest.

\section{References}

1. Kazandjian, D. Multiple myeloma epidemiology and survival: A unique malignancy. In Seminars in Oncology; WB Saunders: Philadelphia, PA, USA, 2016; pp. 676-681.

2. Palumbo, A.; Bringhen, S.; Ludwig, H.; Dimopoulos, M.A.; Bladé, J.; Mateos, M.V.; Rosiñol, L.; Boccadoro, M.; Cavo, M.; Lokhorst, H.; et al. Personalized therapy in multiple myeloma according to patient age and vulnerability: A report of the European Myeloma Network (EMN). Blood 2011, 118, 4519-4529. [CrossRef] [PubMed]

3. Palumbo, A.; Anderson, K. Multiple myeloma. N. Engl. J. Med. 2011, 364, 1046-1060. [CrossRef] [PubMed]

4. Thorsteinsdottir, S.; Dickman, P.W.; Landgren, O.; Blimark, C.; Hultcrantz, M.; Turesson, I.; Björkholm, M.; Kristinsson, S.Y. Dramatically improved survival in multiple myeloma patients in the recent decade: Results from a Swedish population-based study. Haematologica 2018, 103, e412-e415. [CrossRef] [PubMed]

5. Howlader, N.; Noone, A.M.; Krapcho, M.; Miller, D.; Brest, A.; Yu, M.; Ruhl, J.; Tatalovich, Z.; Mariotto, A.; Lewis, D.R.; et al. SEER Cancer Statistics Review (1975-2017). In Bethesda; 2020. Available online: https: //seer.cancer.gov/csr/1975_2017/ (accessed on 3 May 2020).

6. Fonseca, R.; Abouzaid, S.; Bonafede, M.; Cai, Q.; Parikh, K.; Cosler, L.; Richardson, P. Trends in overall survival and costs of multiple myeloma, 2000-2014. Leukemia 2017, 31, 1915-1921. [CrossRef]

7. Dimopoulos, M.A.; Jakubowiak, A.J.; McCarthy, P.L.; Orlowski, R.Z.; Attal, M.; Bladé, J.; Goldschmidt, H.; Weisel, K.C.; Ramasamy, K.; Zweegman, S.; et al. Developments in continuous therapy and maintenance treatment approaches for patients with newly diagnosed multiple myeloma. Blood Cancer J. 2020, $10,17$. [CrossRef]

8. Cildir, G.; Low, K.C.; Tergaonkar, V. Noncanonical NF-кB Signaling in Health and Disease. Trends Mol. Med. 2016, 22, 414-429. [CrossRef]

9. Puar, Y.R.; Shanmugam, M.K.; Fan, L.; Arfuso, F.; Sethi, G.; Tergaonkar, V. Evidence for the involvement of the master transcription factor NF- $\mathrm{BB}$ in cancer initiation and progression. Biomedicines 2018, 6, 82. [CrossRef]

10. Chew, C.L.; Conos, S.A.; Unal, B.; Tergaonkar, V. Noncoding RNAs: Master Regulators of Inflammatory Signaling. Trends Mol. Med. 2018, 24, 66-84. [CrossRef]

11. Chesi, M.; Bergsagel, P.L. Molecular pathogenesis of multiple myeloma: Basic and clinical updates. Int. J. Hematol. 2013, 97, 313-323. [CrossRef]

12. Bergsagel, P.L.; Nardini, E.; Brents, L.; Chesi, M.; Kuehl, W.M. IgH translocations in multiple myeloma: A nearly universal event that rarely involves c-myc. In Current Topics in Microbiology and Immunology; Springer: Berlin/Heidelberg, Germany, 1997; pp. 283-287.

13. Fonseca, R.; Debes-Marun, C.S.; Picken, E.B.; Dewald, G.W.; Bryant, S.C.; Winkler, J.M.; Blood, E.; Oken, M.; Santana-Dávila, R.; González-Paz, N.; et al. The recurrent IgH translocations are highly associated with nonhyperdiploid variant multiple myeloma. Blood 2003, 102, 2562-2567. [CrossRef]

14. Lohr, J.G.; Stojanov, P.; Carter, S.L.; Cruz-Gordillo, P.; Lawrence, M.S.; Auclair, D.; Sougnez, C.; Knoechel, B.; Gould, J.; Saksena, G.; et al. Widespread genetic heterogeneity in multiple myeloma: Implications for targeted therapy. Cancer Cell 2014, 25, 91-101. [CrossRef] [PubMed]

15. Demchenko, Y.N.; Michael Kuehl, W. A critical role for the NFkB pathway in multiple myeloma. Oncotarget 2010, 1, 59-68. [CrossRef] [PubMed]

16. Flynt, E.; Bisht, K.; Sridharan, V.; Ortiz, M.; Towfic, F.; Thakurta, A. Prognosis, Biology, and Targeting of TP53 Dysregulation in Multiple Myeloma. Cells 2020, 9, 287. [CrossRef]

17. Keats, J.J.; Fonseca, R.; Chesi, M.; Schop, R.; Baker, A.; Chng, W.-J.; Van Wier, S.; Tiedemann, R.; Shi, C.-X.; Sebag, M.; et al. Promiscuous Mutations Activate the Noncanonical NF-кB Pathway in Multiple Myeloma. Cancer Cell 2007, 12, 131-144. [CrossRef]

18. Walker, B.A.; Wardell, C.P.; Chiecchio, L.; Smith, E.M.; Boyd, K.; Neri, A.; Davies, F.E.; Ross, F.M.; Morgan, G.J. Aberrant global methylation patterns affect the molecular pathogenesis and prognosis of multiple myeloma. Blood 2011, 117, 553-562. [CrossRef] [PubMed]

19. Hodge, D.R.; Peng, B.; Cherry, J.C.; Hurt, E.M.; Fox, S.D.; Kelley, J.A.; Munroe, D.J.; Farrar, W.L. Interleukin 6 supports the maintenance of p53 tumor suppressor gene promoter methylation. Cancer Res. 2005, 65, 4673-4682. [CrossRef] 
20. De Smedt, E.; Lui, H.; Maes, K.; De Veirman, K.; Menu, E.; Vanderkerken, K.; De Bruyne, E. The epigenome in multiple myeloma: Impact on tumor cell plasticity and drug response. Front. Oncol. 2018, 8, 566. [CrossRef]

21. Iannetti, A.; Ledoux, A.C.; Tudhope, S.J.; Sellier, H.; Zhao, B.; Mowla, S.; Moore, A.; Hummerich, H.; Gewurz, B.E.; Cockell, S.J.; et al. Regulation of p53 and Rb Links the Alternative NF-kB Pathway to EZH2 Expression and Cell Senescence. PLoS Genet. 2014, 10, e1004642. [CrossRef]

22. Rizq, O.; Mimura, N.; Oshima, M.; Saraya, A.; Koide, S.; Kato, Y.; Aoyama, K.; Nakajima-Takagi, Y.; Wang, C.; Chiba, T.; et al. Dual Inhibition of EZH2 and EZH1 Sensitizes PRC2-Dependent Tumors to Proteasome Inhibition. Clin. Cancer Res. 2017, 23, 4817-4830. [CrossRef]

23. Guo, M.; Price, M.J.; Patterson, D.G.; Barwick, B.G.; Haines, R.R.; Kania, A.K.; Bradley, J.E.; Randall, T.D.; Boss, J.M.; Scharer, C.D. EZH2 Represses the B Cell Transcriptional Program and Regulates Antibody-Secreting Cell Metabolism and Antibody Production. J. Immunol. 2018, 200, 1039-1052. [CrossRef]

24. Annunziata, C.M.; Davis, R.E.; Demchenko, Y.; Bellamy, W.; Gabrea, A.; Zhan, F.; Lenz, G.; Hanamura, I.; Wright, G.; Xiao, W.; et al. Frequent Engagement of the Classical and Alternative NF-кB Pathways by Diverse Genetic Abnormalities in Multiple Myeloma. Cancer Cell 2007, 12, 115-130. [CrossRef] [PubMed]

25. Demchenko, Y.N.; Glebov, O.K.; Zingone, A.; Keats, J.J.; Leif Bergsagel, P.; Michael Kuehl, W. Classical and/or alternative NF-кB pathway activation in multiple myeloma. Blood 2010, 115, 3541-3552. [CrossRef]

26. Pires, B.R.B.; Silva, R.C.M.C.; Ferreira, G.M.; Abdelhay, E. NF-kappaB: Two sides of the same coin. Genes 2018, 9, 24. [CrossRef] [PubMed]

27. Eluard, B.; Thieblemont, C.; Baud, V. NF-кB in the New Era of Cancer Therapy. Trends Cancer 2020, 6, 677-687. [CrossRef] [PubMed]

28. Dehghanifard, A.; Kaviani, S.; Abroun, S.; Mehdizadeh, M.; Saiedi, S.; Maali, A.; Ghaffari, S.; Azad, M. Various Signaling Pathways in Multiple Myeloma Cells and Effects of Treatment on These Pathways. Clin. Lymphoma Myeloma Leuk. 2018, 18, 311-320. [CrossRef] [PubMed]

29. Zhang, Q.; Lenardo, M.J.; Baltimore, D. 30 Years of NF-kB: A Blossoming of Relevance to Human Pathobiology. Cell 2017, 168, 37-57. [CrossRef] [PubMed]

30. Shih, V.F.S.; Tsui, R.; Caldwell, A.; Hoffmann, A. A single NFkB system for both canonical and non-canonical signaling. Cell Res. 2011, 21, 86-102. [CrossRef]

31. Xia, Y.; Shen, S.; Verma, I.M. NF-kB, an active player in human cancers. Cancer Immunol. Res. 2014, 2, $823-830$. [CrossRef]

32. Li, Y.; Cheng, H.S.; Chng, W.J.; Tergaonkar, V.; Cleaver, J.E. Activation of mutant TERT promoter by RAS-ERK signaling is a key step in malignant progression of BRAF-mutant human melanomas. Proc. Natl. Acad. Sci. USA 2016, 113, 14402-14407. [CrossRef]

33. Akincilar, S.C.; Low, K.C.; Liu, C.Y.; Yan, T.D.; Oji, A.; Ikawa, M.; Li, S.; Tergaonkar, V. Quantitative assessment of telomerase components in cancer cell lines. FEBS Lett. 2015, 589, 974-984. [CrossRef]

34. Khattar, E.; Maung, K.Z.Y.; Chew, C.L.; Ghosh, A.; Mok, M.M.H.; Lee, P.; Zhang, J.; Chor, W.H.J.; Cildir, G.; Wang, C.Q.; et al. Rap1 regulates hematopoietic stem cell survival and affects oncogenesis and response to chemotherapy. Nat. Commun. 2019, 10,1-14. [CrossRef] [PubMed]

35. Ozturk, M.B.; Li, Y.; Tergaonkar, V. Current insights to regulation and role of telomerase in human diseases. Antioxidants 2017, 6, 17. [CrossRef] [PubMed]

36. Cildir, G.; Pant, H.; Lopez, A.F.; Tergaonkar, V. The transcriptional program, functional heterogeneity, and clinical targeting of mast cells. J. Exp. Med. 2017, 214, 2491-2506. [CrossRef] [PubMed]

37. Siveen, K.S.; Nguyen, A.H.; Lee, J.H.; Li, F.; Singh, S.S.; Kumar, A.P.; Low, G.; Jha, S.; Tergaonkar, V.; Ahn, K.; et al. Negative regulation of signal transducer and activator of transcription-3 signalling cascade by lupeol inhibits growth and induces apoptosis in hepatocellular carcinoma cells. Br. J. Cancer 2014, 111, 1327-1337. [CrossRef] [PubMed]

38. Chen, D.; Frezza, M.; Schmitt, S.; Kanwar, J.; Dou, Q.P. Bortezomib as the First Proteasome Inhibitor Anticancer Drug: Current Status and Future Perspectives. Curr. Cancer Drug Targets 2011, 11, 239-253. [CrossRef]

39. Auphan, N.; DiDonato, J.A.; Rosette, C.; Helmberg, A.; Karin, M. Immunosuppression by glucocorticoids: Inhibition of NF- $\kappa B$ activity through induction of IкB synthesis. Science 1995, 270, 286-290. [CrossRef]

40. Oh, K.-S.; Gottschalk, R.A.; Lounsbury, N.W.; Sun, J.; Dorrington, M.; Baek, S.; Sun, G.; Wang, Z.; Krauss, K.S.; Milner, J.D.; et al. Dual Roles for Ikaros in Regulation of Macrophage Chromatin State and Inflammatory Gene Expression. J. Immunol. 2018, 201, 757-771. [CrossRef] 
41. Krönke, J.; Udeshi, N.D.; Narla, A.; Grauman, P.; Hurst, S.N.; McConkey, M.; Svinkina, T.; Heckl, D.; Comer, E.; Li, X.; et al. Lenalidomide causes selective degradation of IKZF1 and IKZF3 in multiple myeloma cells. Science 2014, 343, 301-305. [CrossRef]

42. Lu, G.; Middleton, R.E.; Sun, H.; Naniong, M.; Ott, C.J.; Mitsiades, C.S.; Wong, K.-K.; Bradner, J.E.; Kaelin, W.G. The myeloma drug lenalidomide promotes the cereblon-dependent destruction of ikaros proteins. Science 2014, 343, 305-309. [CrossRef]

43. Shannon, E.; Sandoval, F.; Greig, N.; Stagg, P. Lenalidomide alone or lenalidomide plus dexamethasone significantly inhibit IgG and IgM in vitro ... A possible explanation for their mechanism of action in treating multiple myeloma. Int. Immunopharmacol. 2012, 12, 441-446. [CrossRef]

44. Moreaux, J.; Legouffe, E.; Jourdan, E.; Quittet, P.; Rème, T.; Lugagne, C.; Moine, P.; Rossi, J.-F.; Klein, B.; Tarte, K. BAFF and APRIL protect myeloma cells from apoptosis induced by interleukin 6 deprivation and dexamethasone. Blood 2004, 103, 3148-3157. [CrossRef] [PubMed]

45. Tai, Y.T.; Li, X.F.; Breitkreutz, I.; Song, W.; Neri, P.; Catley, L.; Podar, K.; Hideshima, T.; Chauhan, D.; Raje, N.; et al. Role of B-cell-activating factor in adhesion and growth of human multiple myeloma cells in the bone marrow microenvironment. Cancer Res. 2006, 66, 6675-6682. [CrossRef] [PubMed]

46. Mondello, P.; Cuzzocrea, S.; Navarra, M.; Mian, M. Bone marrow micro-environment is a crucial player for myelomagenesis and disease progression. Oncotarget 2017, 8, 20394-20409. [CrossRef] [PubMed]

47. Pinzone, J.J.; Hall, B.M.; Thudi, N.K.; Vonau, M.; Qiang, Y.-W.; Rosol, T.J.; Shaughnessy, J.D. The role of Dickkopf-1 in bone development, homeostasis, and disease. Blood 2009, 113, 517-525. [CrossRef]

48. Hata, H. Bone lesions and macrophage inflammatory protein-1 alpha (MIP-1 $\alpha$ ) in human multiple myeloma. Leuk. Lymphoma 2005, 46, 967-972. [CrossRef]

49. Chng, W.J.; Glebov, O.; Bergsagel, P.L.; Kuehl, W.M. Genetic events in the pathogenesis of multiple myeloma. Best Pract. Res. Clin. Haematol. 2007, 20, 571-596. [CrossRef]

50. de Weers, M.; Tai, Y.-T.; van der Veer, M.S.; Bakker, J.M.; Vink, T.; Jacobs, D.C.H.; Oomen, L.A.; Peipp, M.; Valerius, T.; Slootstra, J.W.; et al. Daratumumab, a Novel Therapeutic Human CD38 Monoclonal Antibody, Induces Killing of Multiple Myeloma and Other Hematological Tumors. J. Immunol. 2011, 186, 1840-1848. [CrossRef]

51. Kaku, H.; Horikawa, K.; Obata, Y.; Kato, I.; Okamoto, H.; Sakaguchi, N.; Gerondakis, S.; Takatsu, K. NF-kB is required for CD38-mediated induction of $\mathrm{Cg} 1$ germline transcripts in murine B. lymphocytes. Int. Immunol. 2002, 14, 1055-1064. [CrossRef]

52. Qian, Y.; Chen, C.; Ma, L.; Wang, Z.; Wang, L.-F.; Zuo, L.; Yang, Y.; Huang, X.; Jiang, M.; Wang, X.; et al. CD38 Deficiency Promotes Inflammatory Response Through Activating Sirt1/NF-kB-Mediated Inhibition of TLR2 Expression in Macrophages. Mediat. Inflamm. 2018, 2018, 1-13. [CrossRef]

53. Neri, P.; Kumar, S.; Fulciniti, M.T.; Vallet, S.; Chhetri, S.; Mukherjee, S.; Tai, Y.; Chauhan, D.; Tassone, P.; Venuta, S.; et al. Neutralizing B-cell-activating factor antibody improves survival and inhibits osteoclastogenesis in a severe combined immunodeficient human multiple myeloma model. Clin. Cancer Res. 2007, 13, 5903-5909. [CrossRef]

54. Blimark, C.; Holmberg, E.; Mellqvist, U.H.; Landgren, O.; Björkholm, M.; Hultcrantz, M.; Kjellander, C.; Turesson, I.; Kristinsson, S.Y. Multiple myeloma and infections: A population-based study on 9253 multiple myeloma patients. Haematologica 2015, 100, 107-113. [CrossRef] [PubMed]

55. Nucci, M.; Anaissie, E. Infections in Patients with Multiple Myeloma in the Era of High-Dose Therapy and Novel Agents. Clin. Infect. Dis. 2009, 49, 1211-1225. [CrossRef] [PubMed]

56. Teh, B.W.; Harrison, S.J.; Worth, L.J.; Thursky, K.A.; Slavin, M.A. Infection risk with immunomodulatory and proteasome inhibitor-based therapies across treatment phases for multiple myeloma: A systematic review and meta-analysis. Eur. J. Cancer 2016, 67, 21-37. [CrossRef]

57. Li, J.; Li, Y.; Huang, B.; Zheng, D.; Chen, M.; Zhou, Z. Drug-Induced Modulation of T Lymphocytes as a Potential Mechanism of Susceptibility to Infections in Patients with Multiple Myeloma During Bortezomib Therapy. Cell Biochem. Biophys. 2014, 71, 457-464. [CrossRef] [PubMed]

58. Offidani, M.; Corvatta, L.; Bringhen, S.; Gentili, S.; Gay, F.; Maracci, L.; Boccadoro, M.; Leoni, P.; Palumbo, A. Infection Complications in 476 Patients with Newly Diagnosed Multiple Myeloma Treated with Lenalidomide or Bortezomib Combinations. Blood 2015, 126, 5365. [CrossRef]

59. Prescott, J.; Cook, S. Targeting IKK $\beta$ in Cancer: Challenges and Opportunities for the Therapeutic Utilisation of IKK $\beta$ Inhibitors. Cells 2018, 7, 115. [CrossRef] 
60. Goldstein, D.A. Denosumab for bone lesions in multiple myeloma-What is its value? Haematologica 2018, 103, 753-754. [CrossRef]

61. Taniguchi, K.; Karin, M. NF-B, inflammation, immunity and cancer: Coming of age. Nat. Rev. Immunol. 2018, 18, 309-324. [CrossRef]

62. Ben-Neriah, Y.; Karin, M. Inflammation meets cancer, with NF- $\mathrm{B}$ as the matchmaker. Nat. Immunol. 2011, 12, 715-723. [CrossRef]

63. Raje, N.S.; Moreau, P.; Terpos, E.; Benboubker, L.; Grzaśko, N.; Holstein, S.A.; Oriol, A.; Huang, S.-Y.; Beksac, M.; Kuliczkowski, K.; et al. Phase 2 study of tabalumab, a human anti-B-cell activating factor antibody, with bortezomib and dexamethasone in patients with previously treated multiple myeloma. Br. J. Haematol. 2017, 176, 783-795. [CrossRef]

64. Liu, J.; Sudom, A.; Min, X.; Cao, Z.; Gao, X.; Ayres, M.; Lee, F.; Cao, P.; Johnstone, S.; Plotnikova, O.; et al. Structure of the nuclear factor $\mathrm{kB}$-inducing kinase (NIK) kinase domain reveals a constitutively active conformation. J. Biol. Chem. 2012, 287, 27326-27334. [CrossRef] [PubMed]

65. Demchenko, Y.N.; Brents, L.A.; Li, Z.; Bergsagel, L.P.; McGee, L.R.; Kuehl, M.W. Novel inhibitors are cytotoxic for myeloma cells with NFkB inducing kinase-dependent activation of NFkB. Oncotarget 2014, 5, 4554-4566. [CrossRef] [PubMed]

66. Rushe, M.; Silvian, L.; Bixler, S.; Chen, L.L.; Cheung, A.; Bowes, S.; Cuervo, H.; Berkowitz, S.; Zheng, T.; Guckian, K.; et al. Structure of a NEMO/IKK-Associating Domain Reveals Architecture of the Interaction Site. Structure 2008, 16, 798-808. [CrossRef] [PubMed]

67. Habineza Ndikuyeze, G.; Gaurnier-Hausser, A.; Patel, R.; Baldwin, A.S.; May, M.J.; Flood, P.; Krick, E.; Propert, K.J.; Mason, N.J. A Phase I Clinical Trial of Systemically Delivered NEMO Binding Domain Peptide in Dogs with Spontaneous Activated B-Cell like Diffuse Large B-Cell Lymphoma. PLoS ONE 2014, 9, e95404. [CrossRef] [PubMed]

68. Xu, X.; Li, Y.; Bharath, S.R.; Ozturk, M.B.; Bowler, M.W.; Loo, B.Z.L.; Tergaonkar, V.; Song, H. Structural basis for reactivating the mutant TERT promoter by cooperative binding of p52 and ETS1. Nat. Commun. 2018, 9, 3138. [CrossRef]

69. Greil, C.; Engelhardt, M.; Ihorst, G.; Schoeller, K.; Bertz, H.; Marks, R.; Zeiser, R.; Duyster, J.; Einsele, H.; Finke, J.; et al. Allogeneic transplantation of multiple myeloma patients may allow long-term survival in carefully selected patients with acceptable toxicity and preserved quality of life. Haematologica 2019, 104, 370-379. [CrossRef]

70. Esma, F.; Salvini, M.; Troia, R.; Boccadoro, M.; Larocca, A.; Pautasso, C. Melphalan hydrochloride for the treatment of multiple myeloma. Expert Opin. Pharmacother. 2017, 18, 1127-1136. [CrossRef]

71. Kyle, R.A.; Rajkumar, S.V. Multiple myeloma. Blood 2008, 111, 2962-2972. [CrossRef]

72. Chari, A.; Vogl, D.T.; Gavriatopoulou, M.; Nooka, A.K.; Yee, A.J.; Huff, C.A.; Moreau, P.; Dingli, D.; Cole, C.; Lonial, S.; et al. Oral Selinexor-Dexamethasone for Triple-Class Refractory Multiple Myeloma. N. Engl. J. Med. 2019, 381, 727-738. [CrossRef]

73. Bahlis, N.J.; Sutherland, H.; White, D.; Sebag, M.; Lentzsch, S.; Kotb, R.; Venner, C.P.; Gasparetto, C.; Del Col, A.; Neri, P.; et al. Selinexor plus low-dose bortezomib and dexamethasone for patients with relapsed or refractory multiple myeloma. Blood 2018, 132, 2546-2554. [CrossRef]

74. Van Rhee, F.; Szmania, S.M.; Dillon, M.; Van Abbema, A.M.; Li, X.; Stone, M.K.; Garg, T.K.; Shi, J.; Moreno-Bost, A.M.; Yun, R.; et al. Combinatorial efficacy of anti-CS1 monoclonal antibody elotuzumab (HuLuc63) and bortezomib against multiple myeloma. Mol. Cancer Ther. 2009, 8, 2616-2624. [CrossRef] [PubMed]

75. Cho, S.F.; Anderson, K.C.; Tai, Y.T. Targeting B cell maturation antigen (BCMA) in multiple myeloma: Potential uses of BCMA-based immunotherapy. Front. Immunol. 2018, 9, 1821. [CrossRef] [PubMed]

76. Raje, N.; Berdeja, J.; Lin, Y.; Siegel, D.S.; Jagannath, S.; Madduri, D.; Liedtke, M.; Rosenblatt, J.; Maus, M.V.; Turka, A.; et al. Anti-BCMA CAR T-Cell Therapy bb2121 in Relapsed or Refractory Multiple Myeloma. N. Engl. J. Med. 2019, 380, 1726-1737. [CrossRef]

77. Drent, E.; Themeli, M.; Poels, R.; De Jong-Korlaar, R.; Yuan, H.; De Bruijn, J.; Martens, A.C.; Zweegman, S.; Van De Donk, N.W.; Groen, R.; et al. A Rational Strategy for Reducing On-Target Off-Tumor Effects of CD38-Chimeric Antigen Receptors by Affinity Optimization. Mol. Ther. 2017, 25, 1946-1958. [CrossRef] [PubMed] 
78. Chu, J.; He, S.; Deng, Y.; Zhang, J.; Peng, Y.; Hughes, T.; Yi, L.; Kwon, C.-H.; Wang, Q.-E.; Devine, S.M.; et al. Genetic modification of T cells redirected toward CS1 enhances eradication of myeloma cells. Clin. Cancer Res. 2014, 20, 3989-4000. [CrossRef] [PubMed]

79. D'Agostino, M.; Raje, N. Anti-BCMA CAR T-cell therapy in multiple myeloma: Can we do better? Leukemia 2020, 34, 21-34. [CrossRef]

80. Jelinek, T.; Hajek, R. PD-1/PD-L1 inhibitors in multiple myeloma: The present and the future. Oncoimmunology 2016, 5, e1254856. [CrossRef]

81. Gowrishankar, K.; Gunatilake, D.; Gallagher, S.J.; Tiffen, J.; Rizos, H.; Hersey, P. Inducible but Not Constitutive Expression of PD-L1 in Human Melanoma Cells Is Dependent on Activation of NF-kB. PLoS ONE 2015, 10, e0123410. [CrossRef]

82. Blaquiere, N.; Castanedo, G.M.; Burch, J.D.; Berezhkovskiy, L.M.; Brightbill, H.; Brown, S.; Chan, C.; Chiang, P.C.; Crawford, J.J.; Dong, T.; et al. Scaffold-Hopping Approach to Discover Potent, Selective, and Efficacious Inhibitors of NF-ÎB Inducing Kinase. J. Med. Chem. 2018, 61, 6801-6813.

83. Cheng, G.; Mei, X.B.; Yan, Y.; Chen, J.; Zhang, B.; Li, J.; Dong, X.; Lin, N.; Zhou, Y. Identification of new NIK inhibitors by discriminatory analysis-based molecular docking and biological evaluation. Arch. Pharm. (Weinheim) 2019, 352, e1800374. [CrossRef]

84. Takakura, N.; Matsuda, M.; Khan, M.; Hiura, F.; Aoki, K.; Hirohashi, Y.; Mori, K.; Yasuda, H.; Hirata, M.; Kitamura, C.; et al. A novel inhibitor of NF- $\mathrm{kB}$-inducing kinase prevents bone loss by inhibiting osteoclastic bone resorption in ovariectomized mice. Bone 2020, 135, 115316. [CrossRef] [PubMed]

85. Li, Z.; Li, X.; Su, M.-B.; Gao, L.-X.; Zhou, Y.-B.; Yuan, B.; Lyu, X.; Yan, Z.; Hu, C.; Zhang, H.; et al. Discovery of a Potent and Selective NF-кB-Inducing Kinase (NIK) Inhibitor That Has Anti-inflammatory Effects in Vitro and in Vivo. J. Med. Chem. 2020, 63, 4388-4407. [PubMed]

86. Fulciniti, M.; Tassone, P.; Hideshima, T.; Vallet, S.; Nanjappa, P.; Ettenberg, S.A.; Shen, Z.; Patel, N.; Tai, Y.; Chauhan, D.; et al. Anti-DKK1 mAb (BHQ880) as a potential therapeutic agent for multiple myeloma. Blood 2009, 114, 371-379. [CrossRef] [PubMed]

87. Bianchi, G.; Oliva, L.; Cascio, P.; Pengo, N.; Fontana, F.; Cerruti, F.; Orsi, A.; Pasqualetto, E.; Mezghrani, A.; Calbi, V.; et al. The proteasome load versus capacity balance determines apoptotic sensitivity of multiple myeloma cells to proteasome inhibition. Blood 2009, 113, 3040-3049. [CrossRef]

88. Scott, K.; Hayden, P.J.; Will, A.; Wheatley, K.; Coyne, I. Bortezomib for the treatment of multiple myeloma. Cochrane Database Syst. Rev. 2016, 4, CD010816. [CrossRef]

89. Chari, A.; Richardson, P.G.; Romanus, D.; Dimopoulos, M.A.; Sonneveld, P.; Terpos, E.; Hajek, R.; Raju, A.; Palumbo, A.; Cain, L.E.; et al. Real-world outcomes and factors impacting treatment choice in relapsed and/or refractory multiple myeloma (RRMM): A comparison of VRd, KRd, and IRd. Expert Rev. Hematol. 2020, 13, 421-433. [CrossRef]

90. Dimopoulos, M.; Siegel, D.; White, D.J.; Boccia, R.; Iskander, K.S.; Yang, Z.; Kimball, A.S.; Mezzi, K.; Ludwig, H.; Niesvizky, R. Carfilzomib vs bortezomib in patients with multiple myeloma and renal failure: A subgroup analysis of ENDEAVOR. Blood 2019, 133, 147-155. [CrossRef]

91. Dimopoulos, M.A.; Goldschmidt, H.; Niesvizky, R.; Joshua, D.; Chng, W.-J.; Oriol, A.; Orlowski, R.Z.; Ludwig, H.; Facon, T.; Hájek, R.; et al. Carfilzomib or bortezomib in relapsed or refractory multiple myeloma (ENDEAVOR): An interim overall survival analysis of an open-label, randomised, phase 3 trial. Lancet Oncol. 2017, 18, 1327-1337. [CrossRef]

92. van de Donk, N.W. Carfilzomib versus bortezomib: No longer an ENDEAVOR. Lancet Oncol. 2017, 18, 1288-1290. [CrossRef]

93. Siegel, D.S.; Dimopoulos, M.A.; Ludwig, H.; Facon, T.; Goldschmidt, H.; Jakubowiak, A.; San-Miguel, J.; Obreja, M.; Blaedel, J.; Stewart, A.K. Improvement in overall survival with carfilzomib, lenalidomide, and dexamethasone in patients with relapsed or refractory multiple myeloma. J. Clin. Oncol. 2018, 36, 728-734. [CrossRef]

94. Shin, E.M.; Neja, S.A.; Fidan, K.; Chua, J.Y.H.; Chung, T.; Bertin, N.; Tergaonkar, V.; Chng, W.; Ooi, M.G. Lymphocyte cytosolic protein 1 (LCP1) is a novel TRAF3 dysregulation biomarker with potential prognostic value in multiple myeloma. Genome Instab. Dis. 2020. [CrossRef] 
95. Zarnegar, B.J.; Wang, Y.; Mahoney, D.J.; Dempsey, P.W.; Cheung, H.H.; He, J.; Shiba, T.; Yang, X.; Yeh, W.C.; Mak, T.W.; et al. Noncanonical NF- $\mathrm{kB}$ activation requires coordinated assembly of a regulatory complex of the adaptors cIAP1, cIAP2, TRAF2 and TRAF3 and the kinase NIK. Nat. Immunol. 2008, 9, 1371-1378. [CrossRef]

96. Vallabhapurapu, S.; Matsuzawa, A.; Zhang, W.Z.; Tseng, P.H.; Keats, J.J.; Wang, H.; Vignali, D.A.A.; Bergsagel, P.L.; Karin, M. Nonredundant and complementary functions of TRAF2 and TRAF3 in a ubiquitination cascade that activates NIK-dependent alternative NF-KB signaling. Nat. Immunol. 2008, 9, 1364-1370. [CrossRef]

97. Lin, W.W.; Yi, Z.; Stunz, L.L.; Maine, C.J.; Sherman, L.A.; Bishop, G.A. The adaptor protein TRAF3 inhibits interleukin-6 receptor signaling in B cells to limit plasma cell development. Sci. Signal. 2015, 8, ra88. [CrossRef] [PubMed]

98. Mambetsariev, N.; Lin, W.W.; Wallis, A.M.; Stunz, L.L.; Bishop, G.A. TRAF3 deficiency promotes metabolic reprogramming in B cells. Sci. Rep. 2016, 6, 1-9. [CrossRef] [PubMed]

99. Mambetsarieva, N.; Lin, W.W.; Stunza, L.L.; Hansona, B.M.; Hildebranda, J.M.; Bishop, G.A. Nuclear TRAF3 is a negative regulator of CREB in B cells. Proc. Natl. Acad. Sci. USA 2016, 113, 1032-1037. [CrossRef]

100. Xie, P.; Stunz, L.L.; Larison, K.D.; Yang, B.; Bishop, G.A. Tumor Necrosis Factor Receptor-Associated Factor 3 Is a Critical Regulator of B Cell Homeostasis in Secondary Lymphoid Organs. Immunity 2007, 27, $253-267$. [CrossRef]

101. Ma, T.; Sadashivaiah, K.; Chellaiah, M.A. Regulation of sealing ring formation by L-plastin and cortactin in osteoclasts. J. Biol. Chem. 2010, 285, 29911-29924. [CrossRef]

102. Chellaiah, M.A.; Majumdar, S.; Aljohani, H. Peptidomimetic inhibitors of L-plastin reduce the resorptive activity of osteoclast but not the bone forming activity of osteoblasts in vitro. PLoS ONE 2018, 13, e0204209. [CrossRef]

103. Tiedemann, K.; Sadvakassova, G.; Mikolajewicz, N.; Juhas, M.; Sabirova, Z.; Tabariès, S.; Gettemans, J.; Siegel, P.M.; Komarova, S.V. Exosomal Release of L-Plastin by Breast Cancer Cells Facilitates Metastatic Bone Osteolysis. Transl. Oncol. 2019, 12, 462-474. [CrossRef]

104. Klemke, M.; Rafael, M.T.; Wabnitz, G.H.; Weschenfelder, T.; Konstandin, M.H.; Garbi, N.; Autschbach, F.; Hartschuh, W.; Samstag, Y. Phosphorylation of ectopically expressed L-plastin enhances invasiveness of human melanoma cells. Int. J. Cancer 2007, 120, 2590-2599. [CrossRef] [PubMed]

105. Dun, M.D.; Chalkley, R.J.; Faulkner, S.; Keene, S.; Avery-Kiejda, K.A.; Scott, R.J.; Falkenby, L.S.; Cairns, M.J.; Larsen, M.R.; Bradshaw, L.A.; et al. Proteotranscriptomic profiling of 231-BR breast cancer cells: Identification of potential biomarkers and therapeutic targets for brain metastasis. Mol. Cell. Proteom. 2015, 14, 2316-2330. [CrossRef] [PubMed]

106. Inaguma, S.; Riku, M.; Ito, H.; Tsunoda, T.; Ikeda, H.; Kasai, K. GLI1 orchestrates CXCR4/CXCR7 signaling to enhance migration and metastasis of breast cancer cells. Oncotarget 2015, 6, 33648-33657. [CrossRef] [PubMed]

107. Otsuka, M.; Kato, M.; Yoshikawa, T.; Chen, H.; Brown, E.J.; Masuho, Y.; Omata, M.; Seki, N. Differential expression of the L-plastin gene in human colorectal cancer progression and metastasis. Biochem. Biophys. Res. Commun. 2001, 289, 876-881. [CrossRef] [PubMed]

108. Foran, E.; McWilliam, P.; Kelleher, D.; Croke, D.T.; Long, A. The leukocyte protein L-plastin induces proliferation, invasion and loss of E-cadherin expression in colon cancer cells. Int. J. Cancer 2006, 118, 2098-2104. [CrossRef]

109. Ning, Y.; Gerger, A.; Zhang, W.; Hanna, D.L.; Yang, D.; Winder, T.; Wakatsuki, T.; Labonte, M.J.; Stintzing, S.; Volz, N.; et al. Plastin polymorphisms predict gender- and stage-specific colon cancer recurrence after adjuvant chemotherapy. Mol. Cancer Ther. 2014, 13, 528-539. [CrossRef]

110. Fang, Z.-Q.; Zang, W.-D.; Chen, R.; Ye, B.; Wang, X.; Yi, S.; Chen, W.; He, F.; Ye, G. Gene expression profile and enrichment pathways in different stages of bladder cancer. Genet. Mol. Res. 2013, 12, 1479-1489. [CrossRef]

111. Kim, D.S.; Choi, Y.D.; Moon, M.; Kang, S.; Lim, J.B.; Kim, K.Y.; Park, K.M.; Cho, N.H. Composite three-marker assay for early detection of kidney cancer. Cancer Epidemiol. Biomark. Prev. 2013, 22, 390-398. [CrossRef]

112. Dubovsky, J.A.; Chappell, D.L.; Harrington, B.K.; Agrawal, K.; Andritsos, L.A.; Flynn, J.M.; Jones, J.A.; Paulaitis, M.E.; Bolon, B.; Johnson, A.J.; et al. Lymphocyte cytosolic protein 1 is a chronic lymphocytic leukemia membrane-associated antigen critical to niche homing. Blood 2013, 122, 3308-3316. [CrossRef] 
113. Freudenmann, L.K.; Mayer, C.; Rodemann, H.P.; Dittmann, K. Reduced exosomal L-Plastin is responsible for radiation-induced bystander effect. Exp. Cell Res. 2019, 383, 111498. [CrossRef]

114. Bosseler, M.; Marani, V.; Broukou, A.; Lequeux, A.; Kaoma, T.; Schlesser, V.; François, J.H.; Palissot, V.; Berchem, G.J.; Aouali, N.; et al. Inhibition of HIF1 $\alpha$-dependent upregulation of phospho-L-Plastin resensitizes multiple myeloma cells to frontline therapy. Int. J. Mol. Sci. 2018, 19, 1551. [CrossRef] [PubMed]

115. Majumdar, S.; Wadajkar, A.S.; Aljohani, H.; Reynolds, M.A.; Kim, A.J.; Chellaiah, M. Engineering of L-Plastin Peptide-Loaded Biodegradable Nanoparticles for Sustained Delivery and Suppression of Osteoclast Function In Vitro. Int. J. Cell Biol. 2019, 2019, 6943986. [CrossRef] [PubMed]

116. Shinohara, H.; Yasuda, T.; Aiba, Y.; Sanjo, H.; Hamadate, M.; Watarai, H.; Sakurai, H.; Kurosaki, T. PKC $\beta$ regulates BCR-mediated IKK activation by facilitating the interaction between TAK1 and CARMA1. J. Exp. Med. 2005, 202, 1423-1431. [CrossRef]

117. Stadanlick, J.E.; Kaileh, M.; Karnell, F.G.; Scholz, J.L.; Miller, J.P.; Quinn, W.J.; Brezski, R.J.; Treml, L.S.; Jordan, K.A.; Monroe, J.G.; et al. Tonic B cell antigen receptor signals supply an NF- $\mathrm{B}$ substrate for prosurvival BLyS signaling. Nat. Immunol. 2008, 9, 1379-1387. [CrossRef] [PubMed]

118. Shinzawa, M.; Konno, H.; Qin, J.; Akiyama, N.; Miyauchi, M.; Ohashi, H.; Miyamoto-Sato, H.; Yanagawa, H.; Akiyama, T.; Inoue, J.-i. Catalytic subunits of the phosphatase calcineurin interact with NF-kB-inducing kinase (NIK) and attenuate NIK-dependent gene expression. Sci. Rep. 2015, 5, 10758. [CrossRef] [PubMed]

119. Wicker, L.S.; Boltz, R.C.; Matt, V.; Nichols, E.A.; Peterson, L.B.; Sigal, N.H. Suppression of B cell activation by cyclosporin A, FK506 and rapamycin. Eur. J. Immunol. 1990, 20, 2277-2283. [CrossRef]

120. Tan, D.; Chng, W.J.; Chou, T.; Nawarawong, W.; Hwang, S.Y.; Chim, C.S.; Chen, W.; Durie, B.G.M.; Lee, J.H. Management of multiple myeloma in Asia: Resource-stratified guidelines. Lancet Oncol. 2013, 14, e571-e581. [CrossRef]

121. Fonseca, R.; Bergsagel, P.L.; Drach, J.; Shaughnessy, J.; Gutierrez, N.; Stewart, A.K.; Morgan, G.; Van Ness, B.; Chesi, M.; Minvielle, S.; et al. International Myeloma Working Group molecular classification of multiple myeloma: Spotlight review. Leukemia 2009, 23, 2210-2221. [CrossRef]

122. Varga, G.; Mikala, G.; Andrikovics, H.; Koszarska, M.; Balassa, K.; Ádám, E.; Kozma, A.; Tordai, A.; Masszi, T. NFKB1 -94ins/delATTG polymorphism is a novel prognostic marker in first line-treated multiple myeloma. Br. J. Haematol. 2015, 168, 679-688. [CrossRef]

123. Kumar, S.; Kaufman, J.L.; Gasparetto, C.; Mikhael, J.; Vig, R.; Pegouri, B.; Benboubker, R.; Facon, T.; Amiot, M.; Moreau, P.; et al. Efficacy of venetoclax as targeted therapy for relapsed/refractory $t(11 ; 14)$ multiple myeloma. Blood 2017, 130, 2401-2409. [CrossRef]

124. Martinez-Garcia, E.; Popovic, R.; Min, D.J.; Sweet, S.M.M.; Thomas, P.M.; Zamdborg, L.; Heffner, A.; Will, C.; Lamy, L.; Staudt, L.M.; et al. The MMSET histone methyl transferase switches global histone methylation and alters gene expression in $\mathrm{t}(4 ; 14)$ multiple myeloma cells. Blood 2011, 117, 211-220. [CrossRef] [PubMed]

125. Coussens, N.P.; Kales, S.C.; Henderson, M.J.; Lee, O.W.; Horiuchi, K.Y.; Wang, Y.; Chen, Q.; Kuznetsova, E.; $\mathrm{Wu}$, J.; Chakka, S.; et al. High-throughput screening with nucleosome substrate identifies small-molecule inhibitors of the human histone lysine methyltransferase NSD2. J. Biol. Chem. 2018, 293, 13750-13765. [CrossRef]

126. Brighton, T.A.; Khot, A.; Harrison, S.J.; Ghez, D.; Weiss, B.M.; Kirsch, A.; Magen, H.; Gironella, M.; Oriol, A.; Streetly, M.; et al. Randomized, double-blind, placebo-controlled, multicenter study of siltuximab in high-risk smoldering multiple myeloma. Clin. Cancer Res. 2019, 25, 3772-3775. [CrossRef]

127. Jonsson, B.; Nilsson, K.; Nygren, P.; Larsson, R. SDZ PSC-833-A novel potent in vitro chemosensitizer in multiple myeloma. Anticancer Drugs 1992, 3, 641-646. [CrossRef] [PubMed]

128. Friedenberg, W.R.; Rue, M.; Blood, E.A.; Dalton, W.S.; Shustik, C.; Larson, R.A.; Sonneveld, P.; Greipp, P.R. Phase III study of PSC-833 (valspodar) in combination with vincristine, doxorubicin, and dexamethasone (valspodar/VAD) versus VAD alone in patients with recurring or refractory multiple myeloma (E1A95): A trial of the Eastern Cooperative Oncology Group. Cancer 2006, 106, 830-838. [CrossRef] [PubMed]

129. Fassmannová, D.; Sedlák, F.; Sedláček, J.; Špička, I.; Grantz Šašková, K. Nelfinavir Inhibits the TCF11/Nrf1Mediated Proteasome Recovery Pathway in Multiple Myeloma. Cancers 2020, 12, 1065. [CrossRef]

130. Reddi, D.M.; Lu, C.M.; Fedoriw, G.; Liu, Y.; Wang, F.F.; Ely, S.; Boswell, E.L.; Louissaint, A.; Arcasoy, M.O.; Goodman, B.K.; et al. Myeloid neoplasms secondary to plasma cell myeloma: An intrinsic predisposition or therapy-related phenomenon? A clinicopathologic study of 41 cases and correlation of cytogenetic features with treatment regimens. Am. J. Clin. Pathol. 2012, 138, 855-866. [CrossRef] 
131. Klimek, V.M. Recent advances in the management of therapy-related myelodysplastic syndromes and acute myeloid leukemia. Curr. Opin. Hematol. 2013, 20, 137-143. [CrossRef]

132. Pemmaraju, N.; Shah, D.; Kantarjian, H.; Orlowski, R.Z.; Nogueras González, G.M.; Baladanayuthapani, V.; Jain, N.; Wagner, V.; Garcia-Manero, G.; Shah, J.; et al. Characteristics and outcomes of patients with multiple myeloma who develop therapy-related myelodysplastic syndrome, chronic myelomonocytic leukemia, or acute myeloid leukemia. Clin. Lymphoma Myeloma Leuk. 2015, 15, 110-114. [CrossRef]

133. Fernández-Caballero, M.; Salmerón, D.; Dolores Chirlaque, M.; Chen-Liang, T.H.; Hurtado, A.M.; García Malo, M.D.; Ortuño, F.J.; Roldán, V.; Vicente, V.; Jerez, A.; et al. Increasing therapy-related myeloid neoplasms in multiple myeloma. Eur. J. Clin. Investig. 2018, 49, e13050. [CrossRef]

(C) 2020 by the authors. Licensee MDPI, Basel, Switzerland. This article is an open access article distributed under the terms and conditions of the Creative Commons Attribution (CC BY) license (http://creativecommons.org/licenses/by/4.0/). 